\title{
Über die allmähliche Verfertigung der Gedanken beim Reden
}

\author{
AN RÜHLE VON LILIENSTERN
}

Wenn du etwas wissen willst und es durch Meditation nicht finden kannst, so rate ich dir, mein lieber, sinnreicher Freund, mit dem nächsten Bekannten, der dir aufstößt, darüber zu sprechen. Es braucht nicht eben ein scharfdenkender Kopf zu sein, auch meine ich es nicht so, als ob du ihn darum befragen solltest: nein! Vielmehr sollst du es ihm selber allererst erzählen.

Es liegt ein sonderbarer Quell der Begeisterung für denjenigen, der spricht, in einem menschlichen Antlitz, das ihm gegenübersteht; und ein Blick, der uns einen halbausgedrückten Gedanken schon als begriffen ankündigt, schenkt uns oft den Ausdruck für die ganze andere Hälfte desselben. Ich glaube, daß mancher große Redner, in dem Augenblick, da er den Mund aufmachte, noch nicht wußte, was er sagen würde. Aber die Überzeugung, daß er die ihm nötige Gedankenfülle schon aus den Umständen, und der daraus resultierenden Erregung seines Gemüts schöpfen würde, machte ihn dreist genug, den Anfang, auf gutes Glück hin, zu setzen.

Hölderlin an Böhlendorf, 1802

Schreibe doch nur mir bald. Ich brauche Deine reinen Töne. Die Psyche unter Freunden, das Entstehen des Gedankens im Gespräch und Brief ist Künstlern nötig. 